\title{
Information of Technology Service Governance Capability Level Audit on Khairun Ternate University (Case Study, System Information of Kubermas)
}

\author{
Satria Dwi Surya *, Amal Khairan, MS Ahmad, Hairil Kurniadi Sirajuddin, Zainuddin \\ Department of Informatics, Faculty of Engineering, Universitas Khairun, Indonesia.
}

\begin{abstract}
The Information system KUBERMAS (SIMAS) in an organization or information management plays an important role as an asset for the company, because it is very necessary for good and structured management of the information system. The purpose of this study was to see the results of the level of information technology capability at the LPPM Khairun Ternate University using the COBIT 5 framework in order to help universities in IT strategy and IT services. The results of the SIMAS audit at the capability level using the COBIT 5 framework were found at an average level of 2 managed processes. The result ability level or SIMAS ability level at LPPM Khairun University in the whole process of the MEA01 and BAI01 domain is at level 2 which is managed with a value process of 2.21 at this level the process has been implemented and managed appropriately and maintained. Management that has been set is controlled and executed.
\end{abstract}

Keywords: Audit, Information System, KUBERMAS Khairun University

\section{Introduction}

The role of information technology is to add value in a company or education service sector.[1] The Institute for Research and Community Service (LPPM) is one of the education services sectors at Khairun University which acts as science and technologyBthrough research programmes. One of information system owned by LPPM as a information management especially in the Lecture section. The KUBERMAS information system (SIMAS) in an organization or information management plays an important role as an asset for the company, Therefore, it is necessary to have a good and structured management of the information system.

The Institute for Research and Community Service (LPPM) is one of the educational service sectors at Khairun University which acts as a driving force for all components in the system to develop science and technology through research programs so that it can grow and develop sustainably, so LPPM must be able to actualize its active role as an education and training center to improve the quality of human resources. COBIT 5 is ISACA's latest generation guide that addresses IT management governance. COBIT is built on the experience of using COBIT for more than 15 years by many companies and users in business environments, IT communities, insurance and security risks [4],

audits in general to determine the reliability and integrity of financial information; compliance with policies, plans, procedures, laws and regulations, and safeguarding assets. Thus, the audit objective requires the accountant to provide an opinion regarding the feasibility of financial reporting in accordance with auditing standards

The management of the KUBERMAS information system (SIMAS) at Khairun University has been carried out, but it has not been managed properly, especially through structured approaches and methods, so it is difficult to measure how big the role of the KUBERMAS information system is. a very important support in a university.

Technology audit has several control standards as a tool to ensure that electronic data processed is correct and standards are used. for this study using the COBIT 5 framework [2]. The COBIT5 framework is a comprehensive standard that helps companies achieve their goals and generate value through effective information technology governance and management [3].

In COBIT 5 there are five domains used in conducting audits. One of the domains used in this research is the MEA01 and BAI01 domains which are

\footnotetext{
*Corresponding author : satriapauwah@gmail.com
} 
the process of assessing the company's needs and the current system still meets or not. While the BAI01 domain is a process of identifying IT solutions that need to be developed, implemented and integrated into business processes.

\section{Method}

\subsection{Reseach Flow}

The research flow is the beginning of the planning stage of the information technology audit that will be made. This design scheme is made based on the flow of work steps. The following is the flow of the research steps made which can be seen in Figure 1.

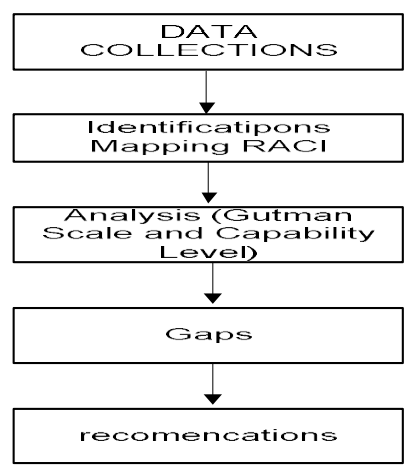

Fig.1. researcher flow chart

\subsection{Data collections}

There are several methods and techniques that can be used in the data collection process, such as Literature Studies, Observations, Interviews, and Questionnaires. If possible, all of these methods can be used, so that the data collected can be truly valid [5].

\subsection{Identifications Mapping RACI}

To obtain a sample from the existing RACI model (Responsibility, Accountability, Consult, and Informed) to determine the level of capability, the respondents from the study amounted to 10 people, including: Head of LPPM as CEO (Chief Executive Officer), Head of Administration and Processing data \& information as $\mathrm{CIO}$ (Chief Information Officer), general administration as CFO (Chief Finance Officer), correspondence administration as Head of IT Operations, financial manager and financial administrator as HITA (Head IT Administration), and General Head of Sub-section as audit

\subsection{Analys Method}

At this stage of analysis, the researcher calculated the questionnaires that had been answered by the respondents, namely in accordance with the RACI table diagram for the MEA01 and BAI01 domains.

Analysis (Guttman Scale and Capability Level) Includes a recapitulation of the answers of each respondent, a recapitulation of the results of the questionnaire calculations using the Guttman scale in each process, to the data interpretation stage that shows the current position of the university's capability level (Current Capability) and the current capability level. (expected level) to the maximum capability level (maximum level). The calculation of the questionnaire to be carried out in this study is as follows:

1. Making a questionnaire using the Guttman scale as a reference.

2. Each questionnaire criteria, namely 'yes' and 'no' will be converted to 1 and 0 .

3. The results of the conversion will then be normalized by dividing the total value by the number of questions at each level, then after normalization, the average calculation is carried out by dividing the total value of answers by the number of respondents.

4. From the calculation results, the final results can be categorized according to the following rules listed in Table 1.

Table 1. Capability Value

\begin{tabular}{|l|l|l|}
\hline $\begin{array}{l}\text { Range } \\
\text { values }\end{array}$ & $\begin{array}{l}\text { Capability } \\
\text { Value }\end{array}$ & Capability level \\
\hline $0-0,50$ & 0,00 & 0 Incomplete Process \\
\hline $0,51-1,50$ & 1,00 & 1 Performed Process \\
\hline $1,51-2,50$ & 2,00 & 2 Managed Process \\
\hline $2,51-3,50$ & 3,00 & 3 Established Process \\
\hline $3,51-4,50$ & 4,00 & 4 Predictable Process \\
\hline $4,51-5,00$ & 5,00 & 5 Optimising Process \\
\hline
\end{tabular}

\subsection{Validations (Guttman and Capability level)}

This validation contains the results of respondents' answers that refer to the domain used. The domains used as references are MEA 01 and BAI 01, then those who have answered the questionnaire will be processed into an excel calculation table in which there is an excel calculation for each domain, which has a statement for each level symbolized by numbers $0-5$ and each level has a number of statements which shows the number of statements symbolized by $(\mathrm{P})$.

\subsection{Recomndations}

The purpose of this recommendation is to be able to obtain the current level of ability that exists at Khairun University and the level of ability expected by Khairun University in the future, namely the information system and these recommendations are expected to be able to provide maximum results in the management of SIMAS information technology at the University.

\section{Results And Discussion}

\subsection{Result}

The initial stage is to prepare an initial plan where the purpose and scope of this research is to audit SIMAS. Khairun University Ternate which is owned by the 
Institute for Research and Student Service (LPPM) at the university. Then at the next stage, namely by making observations, then starting with interviewing the interviewees, they were asked the same basic questions, namely about SIMAS. After that, the researchers distributed questionnaires to find out the current level of capability, and also took documentation, and asked for some data that would later be used for review. References.

There is a next stage, namely the stage of finding problems and validation and developing solutions based on the results of these measurements will be identified based on COBIT 5 using the MEA01 and BAI01 domains which can provide suggestions and recommendations to LPPM. And at the last stage, namely the preparation of results and making reports where the researcher will summarize in the form of a report which consists of collecting data from interviews and questionnaire results, identifying RACI mapping, analysis using (Guttman Scale and Capability level), gap analysis (GAP) and recommendations on each process as well as conclusions and suggestions

\subsection{Analysis Results (Guttman Scale and Capability Level)}

Table 2. Questionnaire display in excel

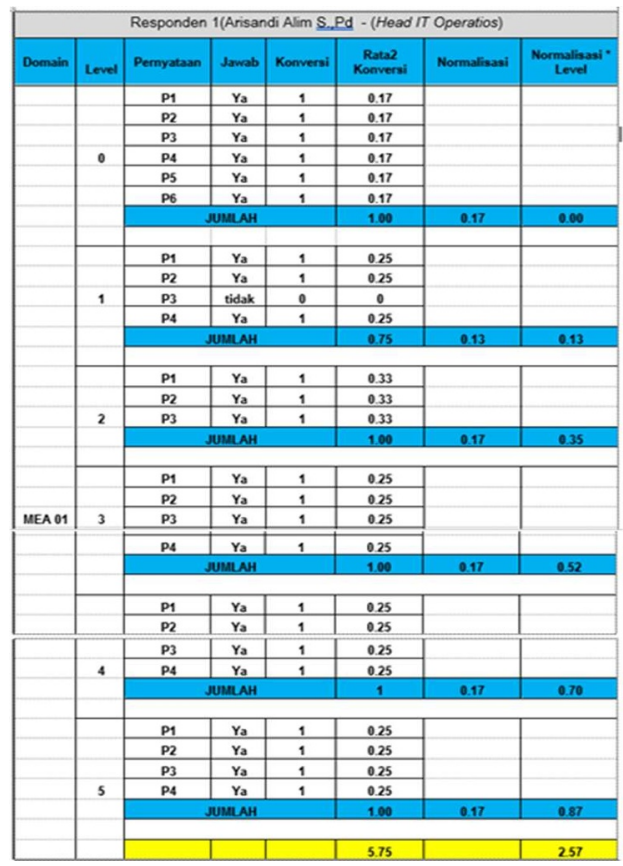

The results of the analysis in table 2 above contain the results of the answers of respondents who have answered the questionnaire which are then processed into an excel calculation table. where in it there is an excel calculation for each domain, which has a statement for each level symbolized by the numbers 0-5 and each level has a number of statements that show the number of statements symbolized by P1-P6.

\subsection{Capability level calculation results}

At this stage the author will present the results of the Capability Level calculation for each MEA 01 (Monitoring, Evaluating, Assessing Performance and Adjustment) and BAI01 (Managing programs and projects) Domains sub-processes. Below is a table recapitulation of MEA01 and BAI01 domain capabilities. It can be seen in Tables 3 and 4 below.

Table 3. MEA01 domain capability recapitulation result

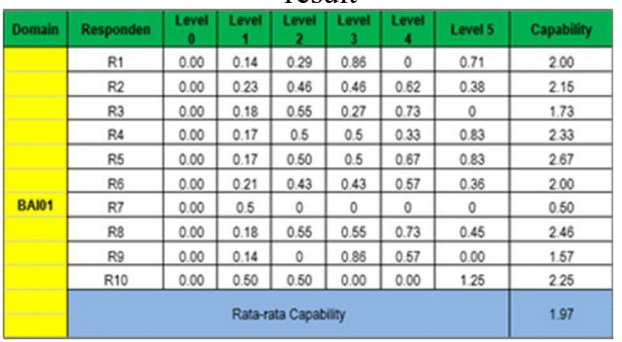

The calculation of BAI01 domain capabilities are as follow :

$$
\begin{aligned}
C L a= & \frac{\varepsilon C l i}{\varepsilon R} \\
C L a= & (2.57+2.45+2.57+2.74+2.40+ \\
& 2.5+2.4+2.5+2.16+2.07) / \varepsilon R \\
C L a= & 2.44 \\
C C= & \frac{\varepsilon C l a+\varepsilon \text { Cpo }}{2} \\
C C= & \frac{2.44+1.97}{2} \\
C C= & 2.21
\end{aligned}
$$

Associated with levels 0-5, where an explanation of level 0 indicates the failure of the business process or not achieving the desired goals. At this level too, there is little or almost no evidence to suggest that the objectives have been achieved, then at level 1, it covers matters related to management (planning, monitoring, proper evaluation process). The management that has been established is well controlled and maintained. Then at level 2, the existing business processes have been managed properly, so that the business processes being run are now more established. Then at level 3, the business processes that have been established are then operated with certain limitations to achieve the final results in accordance with the company's predictions. Then at level 4 , the business processes that have been established are then operated with certain limits to achieve the final results in accordance with the company's predictions. Then at level 5, Predictions that have been executed, are continuously improved to meet the current business objectives and project objectives. The following table recapitulates the calculation results of the MEA01 and BAI01 domain capability values. Can be seen in Table 4. 
Table 4. Recapitulation of MEA01 and BAI01 . domain calculations

\begin{tabular}{|c|c|c|c|}
\hline Domain & Capablity Level & Expected level & Maxi Level \\
\hline MEA01 & 2.44 & 3 & 5 \\
\hline BA 01 & 1.97 & 3 & 5 \\
\hline JUMAH & 4.41 & & \\
\hline $\begin{array}{l}\text { JUMLAH RATA-RATA CAPABIUTY } \\
\text { LEVEL (CAPABIUTY LEVEL ACHIEVED) }\end{array}$ & 221 & & 5 \\
\hline Rating Berdasakan kniteria & $\begin{array}{l}\text { level } 2 \text { Manoged } \\
\text { Processs }\end{array}$ & $\begin{array}{l}\text { Level } 3 \\
\text { Established } \\
\text { Process }\end{array}$ & $\begin{array}{l}\text { Level } 5 \text { Optimise } \\
\text { Procoss }\end{array}$ \\
\hline
\end{tabular}

Table 4 above explains that the value of the capability level (current capability) for each domain is obtained from the results of the recapitulation of each questionnaire which then from the results of the recapitulation are all summed using the formula in chapter 2 while for the results of the target level to be achieved (expected level) the researcher follows journal [2] where the determination of the target level is determined by the level being targeted from the average level obtained. Thus, for the MEA and BAI domains, the average level is now 2.21. This value is in the range of $1.51-2.50$ which is at level 2 where the rating of the criteria is based on the journal [6]

Table 5. Result of capability Domain MEA01 and BAI01

\begin{tabular}{|c|l|c|l|}
\hline Domain & \multicolumn{1}{|c|}{ Keterangan } & $\begin{array}{c}\text { Hasil } \\
\text { Pernitungan }\end{array}$ & Capability Level \\
\hline MEA01 & $\begin{array}{l}\text { Memantau, evaluasi dan menilai } \\
\text { kineria dan penyesuaian }\end{array}$ & 2,44 & Managed Process \\
\hline BAl01 & Mengelola program dan proyek & 1,97 & Managed Process \\
\hline \multicolumn{2}{|c|}{ Ratarata } & 2.21 & Managed Process \\
\hline
\end{tabular}

Based on table 5 the conditions under which there are IT responsibilities and persons in charge. However, the process still depends on the knowledge of certain individuals or parties, the management's authority is limited, so errors may occur, it can be concluded based on the journal [7] that the MEA01 and BAI01 domains being addressed from the capability level are level 3 with a value of 3.00 , then level 3 is called the target level, as well as to get the expected value in the MEA01 and BAI01 domains to determine the target level, namely the level that is being addressed from the average level obtained. And for the maximum level (max level), which is the highest level that will be achieved from the capability level, which is level 5 . After calculating the capability level of the 2 processes contained in the MEA01 and BAI01 domains, each has a process that has the current capability level which is at the 2-managed process level, which means the process has been executed or has been carried out. The capability level has been managed well, so that the processes being run are now getting better, while the average result of the total capability level is at the 2Managed process level, namely the process has been run or done.

\subsection{Domain analisys MEA01}

In the recapitulation of the capability results in the process of monitoring, evaluating, assessing performance and adjusting the domain (MEA01) such as an explanation related to the process capability level achieved, the MEA01 domain is in process 2, namely managed process. and 2.8 where the process has been implemented and managed (planned, monitored and adapted) appropriately to the work product, controlled and maintained. The following are the achievements based on the average MEA01 domain capability:

PA.2.1 Management (Perfomance Management). A measurement of the management of the performance process, where the performance management of LPPM Khairun University has several achievements, namely:

1. The objectives of the process performance are identified.

2. The performance of the process is planned, monitored and adjusted to meet the demand or previous plans.

3. Responsibilities for the process are defined, assigned and communicated.

4. Resources and information needed to carry out a process are identified, provided, allocated and used properly..

Work Product Management (Work Product Management). A measurement related to the work that results from the managed process. In the management of work results have several achievements, namely:

1. The requirements of the process used to produce the product have been defined.

2. Requirements for documentation and control of work results have been defined.

3. Work results are identified, documented and controlled appropriately.

4. The results of the work are reviewed in accordance with the plan to be able to meet the desired needs.

It can be concluded based on the analysis above, that LPPM has implemented and implemented it based on the MEA01 domain, which has been implemented and managed (planned, monitored and adjusted) appropriately for its work products, controlled and maintained properly.

\subsection{Domain Analisys BAI01}

In the recapitulation of the capability results in the process of managing programs and domain projects (BAI01) as well as the explanation regarding the process capability level achieved, the BAI01 domain is in process 2 , namely managed process, it can be seen an explanation of the process capability level attributes where the process has been implemented and managed. appropriately to the product of his work, is developed. The following are the achievements obtained by LPPM Khairun University based on the average BAI01 domain capability:

PA.2.1 PA.2.1 Management (Perfomance Management) A measurement of the management of the performance process, where the management of programs and projects that have been achieved, namely:

1. Ensure proper technology development for SIMAS development.

2. There is a process to improve the quality of the system. 
3. The existence of planning in the management of quality and resources.

4. The existence of program implementation based on the results of the evaluation.

5. PA 2.2 Work Product Management A measurement related to the results of the work produced from the development process that is managed on the product, namely:

6. The existence of internal control in the evaluation of SIMAS information services

regularly.

7. The existence of identification and evaluation of alternative actions in achieving the results expected by internal control.

8. 3. There is an optimization of the comparison of SIMAS's internal control with other universities.

9. 4. There is a system improvement planning process

10. 5. There is a planning process in managing the scope, resources, risks, costs, quality of time and communication.

11. It can be concluded based on the analysis above, that SIMAS development by LPPM has been carried out and implemented based on the BAI01 domain, which has been implemented and has managed programs and projects appropriately for its work products.

\subsection{Gap Analisys}

This gap analysis is carried out to find the difference in the capability level value, obtained with the target level (expected level) to be achieved in determining the target level, while for the results of the target level to be achieved (expected level) researchers follow the journal [2] where the determination of the target level is determined. with the level being targeted from the average level obtained. Thus, for the MEA and BAI domains that are used now, the average value level of 2.21 can be seen in Table 4.36, the value is in the range of 1.51-2.50 which means that it is at level 2 automatically the domain that is being addressed from level 1. capability is level 3 then this level 3 is called the target level (expected level). If the capability level and target level are known, then to get the level of the gap gap with the formula: $X-Y$ where $X$ is the value of the target level and $\mathrm{Y}$ is the value of the capability level that can be obtained. Then the level of the gap gap is $3.00-$ $2.21=0.79$. The following will explain the gap analysis of each domain.

\subsubsection{Analisis Gap MEA01}

The result of the gap analysis in MEA01, which is 0.56 , is obtained from the formula: $\mathrm{X}-\mathrm{Y}$ where $\mathrm{X}$ is the value of the target level and Y is the value of the capability level that can be obtained. Then the level of the gap gap is $3.00-2.44=0.56$. While the level to be achieved (expected level) is at level 3. Where in determining the target level is determined by the value of the level being addressed from the level of the average value obtained. Thus, for the MEA01 domain that is used now, the average value level (current capability) is 2.44 , the value is in the range 1.51-2.50 which means that it is at level 2 automatically MEA01 is being addressed from the capability level is level 3 with a value of 3.00 then level 3 is called the target level (expected level). Where the MEA01 process related to the activities of monitoring and evaluating the performance of SIMAS and monitoring has been going quite well. For the results of the analysis of the gap value of the MEA01 gap. The following are the results of the MEA01 GAP analysis in Table 6 below

Table 6. GAP MEA0 . analysis results

\begin{tabular}{|c|c|c|c|}
\hline & $\begin{array}{c}\text { Curent } \\
\text { Capability }\end{array}$ & $\begin{array}{c}\text { Expected } \\
\text { Capability }\end{array}$ & Gap \\
\hline $\begin{array}{l}\text { MEA01 (Memantau,evaluasi dan } \\
\text { menilai kinerja dan penyesuaian) }\end{array}$ & 2,44 & 3 & 0,56 \\
\hline
\end{tabular}

Where to go to level 3, what the university must do is to have an innovative SIMAS evaluation plan continuously so that existing IT can run well and be developed according to the results of the analysis of activities that have existed before and also maximize activities that are already running quite well.

\subsubsection{Gap BAl01 Analysis}

The result of the gap analysis on BAI01 is 1.03 obtained from the formula: $\mathrm{X}-\mathrm{Y}$ where $\mathrm{X}$ is the value of the target level and $\mathrm{Y}$ is the value of the capability level that can be obtained. Then the level of the gap gap is $3.00-1.97$ $=1.03$. While the level to be achieved (expected level) is at level 3. Where in determining the target level is determined by the value of the level being addressed from the level of the average value obtained. Thus, for the current BAI01 domain, the average value level (current capability) is 1.97 , the value is in the range 1.51 - 2.50, which means that it is at level 2 automatically. BAI01 is being targeted from the capability level is level 3 . with a value of 3.00 then level 3 is called the target level (expected level). Where the BAI01 process is a process related to program development, namely how the program can be updated according to needs and from the results of the evaluation and implementation in order to get better results. For the results of the analysis of the gap value of the BAI01 gap. The following results of BAI01 analysis can be seen in Table 7 below.

Table 7. Results of BAI01 GAP Analysis

\begin{tabular}{|l|c|c|c|}
\hline \multicolumn{1}{|c|}{ Domain } & $\begin{array}{c}\text { Curent } \\
\text { Capability }\end{array}$ & $\begin{array}{c}\text { Expected } \\
\text { Capability }\end{array}$ & Gap \\
\hline $\begin{array}{l}\text { BAl01 (Mengelola program dan } \\
\text { proyek) }\end{array}$ & 1,97 & 3 & 1,03 \\
\hline
\end{tabular}

With the results of the gap obtained to get to level 3, what must be done is to make updates to the system by looking at the shortcomings of the performance and effectiveness of users on the system that has been running previously and also maximizing the system that is running quite well. 


\subsubsection{GAP analysis}

The following are the results of the audit, namely the analysis of the gap in each domain, so that the capability level results are obtained for the entire process. It can be seen in Table 8 below.

Table 8. Results of Overall GAP Analysis

\begin{tabular}{|c|c|c|c|}
\hline \multicolumn{1}{|c|}{ Domain } & $\begin{array}{c}\text { Curent } \\
\text { Capability }\end{array}$ & $\begin{array}{c}\text { Expected } \\
\text { Capability }\end{array}$ & Gap \\
\hline $\begin{array}{l}\text { MEA01 (Memantau,evaluasi dan } \\
\text { menilai kinera dan penyesuaian) }\end{array}$ & 2,44 & 3 & 0,56 \\
\hline $\begin{array}{l}\text { BA0101 (Mengelola program dan } \\
\text { proyek) }\end{array}$ & 1,97 & 3 & 1,03 \\
\hline Rata-rata & 2,21 & \multicolumn{2}{|c|}{0,79} \\
\hline & $\begin{array}{l}\text { Rata rata } \\
\text { capability } \\
\text { louval }\end{array}$ & \multicolumn{2}{|c|}{$\begin{array}{l}\text { Rata rata kesenjangan } \\
\text { keseluruhan domain }\end{array}$} \\
\hline
\end{tabular}

From Table 8 obtained the capability level of MEA01 and BAI01 COBIT 5 domain processes and it can be seen that the average capability level obtained is at Level 2, namely Managed Process. For more details can be seen in Figure 2 below.

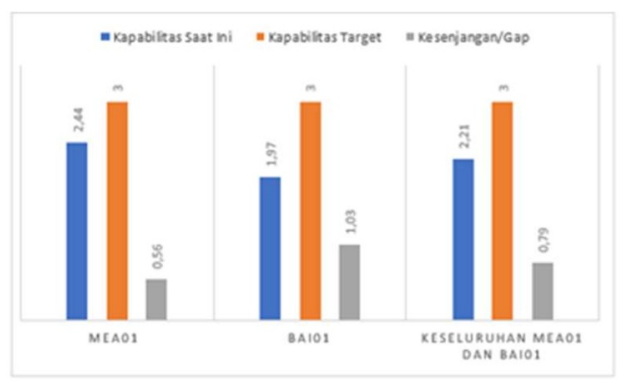

Fig.2. Gap diagram

\subsection{MEA01 recommendation}

The current capability value in the process of monitoring, evaluating and assessing performance and adjustment is 2.44. In meeting the achievement of goals for upgrading to level 3, it takes the role of the MEA01 domain in providing some understanding of awareness of the related LPPM to achieve the target level, so the following are some recommendations given to improve the quality of SIMAS at Khairun University based on the capability attribute model at level 3 .

1. The need for understanding and awareness in carrying out regular maintenance of SIMAS equipment and infrastructure.

2. A monitoring system for SIMAS is required on a regular basis.

3. It is necessary to hold a monthly performance evaluation meeting from SIMAS which aims to determine the progress of SIMAS. Later at the meeting, it can be analyzed starting from additional needs and also deficienciesn.

\subsection{Recomnetdation BAI01}

The current ability score in managing programs and projects is 1.97. In meeting the achievement of goals for upgrading to level 3 , the role of the BAI01 domain is needed in providing some description of the related LPPM to achieve the target level, so the following are some recommendations given to improve the quality of SIMAS at Khairun University based on the capability attribute model at level 3 .

1. There is a need for an evaluation schedule with stakeholders as well as developers or SIMAS Developers on user needs.

2. The need to implement periodic system maintenance in order to get maximum results.

\subsection{General Recommendations of the Overall Process}

Previously, several recommendations were written based on each process in the MEA (Monitor, Evaluate and Assess) and BAI (build, acquire, implement) domains. The following are some additional recommendations in general based on the conditions of SIMAS Khairun University. The overall Capability Level obtained is Level 2 managed process, the target level to be achieved is 3 established process, so the recommendations compiled are as follows:

1. Tighten control and performance of SIMAS users, so that in the future SIMAS can function optimally and can be used for a long time.

2. Implementing the Maps feature in the selection of destinations or student placements at SIMAS in order to make it easier for students to find out the location of placement.

3. Blocking previously registered student accounts who have passed the KUBERMAS course, in order to keep away from things that can later be detrimental.

4. Improve and be consistent in controlling and evaluating more deeply against system deficiencies and then taking quick action in perform maintenance to minimize the problems obtained.

\section{Conclusion}

Based on the results of the capability level audit using the COBIT 5 framework conducted at SIMAS LPPM Khairun University:

1. Information technology managed by the university is used to support business activities carried out by the university, especially LPPM. Based on the use of the guttman scale method, capability level and maturity results, it was found that information technology managed by LPPM has weaknesses, shortcomings and is not optimal for COBIT 5 management practice. From the weaknesses and shortcomings and not optimal information technology managed by LPPM, the authors determine 2 management practices from the MEA and BAI domains to eliminate deficiencies and 
optimize information technology in LPPM, especially SIMAS governance.

2. On the recommendations made to monitor, manage and evaluate the performance of information technology on a regular basis to ensure that information technology continues to run even though there are incidents that occur in LPPM's business processes. The recommendations given also provide direction for understanding and awareness in carrying out periodic maintenance of SIMAS and infrastructure. This recommendation also regulates the management of information technology at LPPM in reminding the need for monthly SIMAS performance evaluation meetings that aim to determine SIMAS progress. Recommendations for managing programs and projects provide input for maintaining and developing the latest features, as well as blocking previously registered student accounts who have passed the KUBERMAS course in order to keep things away from things that can be detrimental.

3. To reduce the gap between the current capability level and the capability level to be achieved, the university must fulfill the managed process so that the current capability level is even better and the capability level that is at level 2 can be increased to level 3. In line with that, university in implementation is getting closer to the goal

\section{References}

[1] R. S. Sepita Sari, Syahril Rizal, "Penerapan Framework COBIT 5 Pada Audit Tata Kelola Teknologi Informasi,” J. Tek. Inform. Univ. Bina Darma, no. April, p. 8, (2014).

[2] Y. F. R. K. C. Imelda Atastina, "Audit Teknologi Informasi menggunakan Framework COBIT 5 Pada Domain DSS (Delivery, Service, and Support) (Studi Kasus: iGracias Telkom University)," vol. 2, no. 1, pp. 1701-1706, 2014.

[3] ISACA, COBIT 5 Framework. (2012).

[4] I. M. M. Matin, "Analisis Keamanan Informasi Data Center Menggunakan COBIT 5," J. Tek. Inform., vol. 10, no. 2, pp. 119-128, (2018), doi: 10.15408/jti.v10i2.7026.

[5] B. H. Purnomo, "Metode dan teknik pengumpulan data dalam Penelitian Tindakan Kelas (Classroom Action Research)," J. Pengemb. Pendidik., vol. 8, no. 1, pp. 251-256, (2011), [Online]. Available: https://media.neliti.com/media/publications/210 251-metodedan-teknik-pengumpulan-datadalam.pdf.

[6] C. Nandhany, S. Mukaromah, and A. Pratama, "Kondisi dimana ada tanggung jawab dan penanggung jawab TI. Namun, proses masih bergantung kepada pengetahuan individu atau pihak tertentu, manajemen tersebut otoritasnya terbatas, sehingga kesalahan mungkin terjadi.," J. Inform. dan Sist. Inf., vol. 1, no. 1, pp. 183191, (2020).

[7] C. Octaria, "Audit Tata Kelola Teknologi Informasi di Universitas Lampung Menggunakan Framework COBIT 5 Fokus Domain EDM (Evaluate, Direct and Monitor)," (2017), [Online]. Available: Universitas Lampung, Bandar Lampung. 